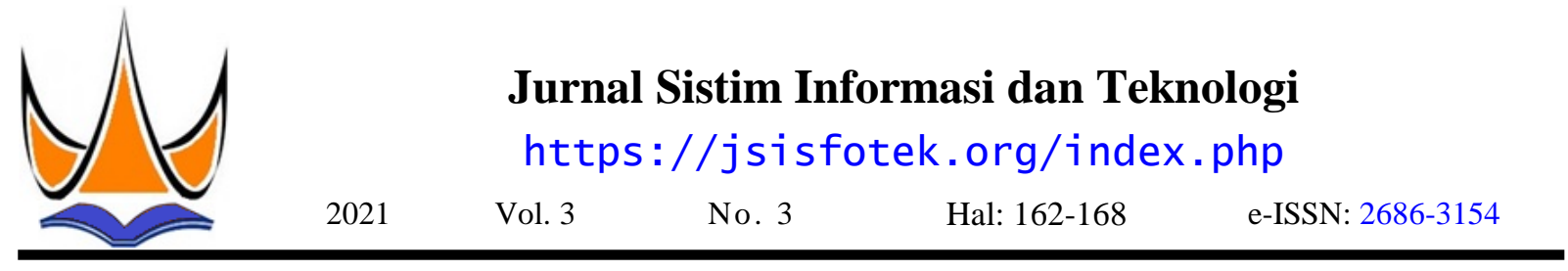

\title{
Klasterisasi Tingkat Masa Studi Tepat Waktu Mahasiswa Menggunakan Algoritma K-Medoids
}

\author{
Fahmi Firzada ${ }^{1 凶}$, Yuhandri Yunus $^{2}$ \\ ${ }^{1,2}$ Universitas Putra Indonesia YPTK Padang \\ fahmifirzada@gmai1.com
}

\begin{abstract}
The period of study on time is one of the parameters of a student's success in completing college to obtain a bachelor's degree. A student is said to have completed his studies on time if he is able to complete his studies less than or equal to the predetermined time. Academic Provides facilities to find out the estimated time of student graduation. By providing information on which students are included in the cluster, they can complete their studies on time and which students do not complete their studies on time. In this study, the data processed were data from students who had graduated in the previous year. Then the data is processed using rapidminer software. This study applies the K-Medoids algorithm in clustering. The result of testing this method is to determine the student clusters who can complete the study period on time and the student clusters who cannot complete the study period on time. This research is expected to contribute to the campus in evaluating the tendency of students to complete their studies on time or not. The results of the evaluation of performance can produce information for study programs, lecturers and students in making policies.
\end{abstract}

Keywords: Clusterization, Student Graduation, K-Medoids Algorithm, Students, Study Period.

\begin{abstract}
Abstrak
Masa studi tepat waktu merupakan salah satu parameter dari keberhasilan seorang mahasiswa dalam menyelesaikan kuliah untuk memperoleh gelar sarjana. Bagi seorang mahasiswa dikatakan telah menyelesaikan studi tepat waktu jika mampu menyelesaikan studinya kurang dari atau sama dengan waktu yang telah ditenkan. Pihak akademik Memberikan fasilitas untuk mengetahui perkiraan waktu lulus mahasiswa. Dengan memberikan informasi mahasiswa mana saja yang masuk dalam cluster dapat menyelesaikan masa studi tepat waktu dan mahasiswa mana saja yang tidak menyelesaikan studi tepat waktu. Pada penelitian ini data yang diolah adalah data mahasiswa yang telah lulus di tahun sebelum nya. Kemudian data diolah menggunakan software rapidminer. Penelitian ini menerapkan algoritma K-Medoids dalam pengklasterisasi. Hasil dari pengujian terhadap metode ini adalah mengetahui cluster mahasiswa yang dapat menyelesaikan masa studi tepat waktu dan cluster mahasiswa yang tidak dapat menyelesaikan masa studi tepat waktu. Penelitian ini diharapkan dapat memberikan kontribusi untuk pihak kampus dalam melakukan evaluasi terhadap kecenderungan mahasiswa dapat menyelesaikan masa studi tepat waktu atau tidak. Hasil evaluasi terhadap kinerja dapat menghasilkan informasi bagi prodi, dosen dan mahasiswa dalam membuat kebijakan.
\end{abstract}

Kata kunci: Klasterisasi, Kelulusan Mahasiswa, Algoritma K-Medoids, Mahasiswa, Masa Studi.

(C) 2021 JSisfotek

\section{Pendahuluan}

Data mining secara simpel dapat diartikan sebagai sebuah proses penyaringan, eksplorasi dan pemodelan dari sebagian besar data untuk menghasilkan pola atau kecenderungan yang pada umumnya tidak disadari keberadaannya [1]. Data mining merupakan akar dari proses KDD, meliputi dugaan algoritma yangmengeksplor data, membangun model dan menciptakan pola yang belum diketahui.

Clustering adalah merupakan suatu prosedur tepat waktu. Data yang di ambil diperoleh dari pusat pengelompokan record, observasi, atau sistem informasi mengenai data mahasiswa angkatan mengelompokkan kelas yang memiliki kesamaan objek 2019-2020 dengan atribut yang digunakan adalah [2]. Clustering berbeda dengan klasifikasi, pada proses Nama Mahasiswa, Jenis Kelamin, Ssatuan Kredit clustering tidak ada variabel target dalam proses Semester (SKS) dan Indeks Prestasi Komulatif (IPK). cluster. Clustering sering digunakan sebagai proses awal dalam data mining. tinggi diminta dapat melangsungkan masa sudi tepat waktu mahasiswa. Kemudian pendidikan yang bermutu bagi mahasiswa sehingga memberikan fasilitas bagi mahasiswa. Salah satu fakta

Diterima: 14-03-2021 | Revisi: 17-04-2021 | Diterbitkan: 30-09-2021 | DOI: 10.37034/jsisfotek.v3i3.60 
yang terjadi dalam lembaga pendidikan tinggi adalah dikarenakan wilayahnya yang tidak terlalu banyak ledakan pertumbuhan data mahasiswa. Ini terjadi setiap terkena penyakit diare, sedangkan cluster C1 tahun dan setiap penerimaan mahasiswa baru. Data ini merupakan daerah yang menjadi perhatian pemerintah berkembang dengan cepat tanpa banyak diketahui dikarenakan daerah-daerah tersebut menjadi pusat keuntungannya bagi manajemen. Pertumbuhan yang penyebaran diare [7].

pesat dari pertambahan data mahasiswa ini telah menciptakan kondisi dimana suatu lembaga pendidikan tinggi atau perguruan tinggi memiliki tumpukan data. Namun pada saat ini, tumpukan data tersebut belum dimanfaatkan secara maksimal. Padahal tumpukan data tersebut dapat menjadi sebuah informasi yang bermanfaat dengan menggunakan suatu teknik yaitu teknik data mining.

Selanjutnya dilakukan penelitian dalam Mengelompokkan Garis Kemiskinan Menurut Provinsi. Hasil akhir yang di tampilkan merupakan pengelompokan garis kemiskinan menurut provinsi. Dimana terdapat 2 cluster, yang pertama cluster dengan nilai kemiskinan terendah dimana di dalamya terdapat 11 provinsi dan yang ke 2 cluster dengan jumlah kemiskinan tertinggi sebanyak 23 provinsi [8]. Manfaat dari penelitian ini memberikan informasi Selanjutnya dilakukan penelitian Pengklasteran kepada mahasiswa AMIK Tunas Bangsa mengenai Dokumen Tentang Dispensasi Nikah. Berdasarkan hasil pengelompokan mahasiswa yang tepat waktu dan yang perhitungan di dapatkan 2 cluster. Yang pertama cluster tidak tepat waktu dalam menyelesaikan masa studi. rendah sebanyak 8 kecamatan dan yang kedua cluster Serta membantu pihak perguruan tinggi dalam tinggi sebanyak 24 kecamatan [9].

melakukan kegiatan-kegiatan dalam melakukan minimalisir jumlah mahasiswa yang diprediksi tidak dapat menyelesaikan masa studi tepat waktu.

Selanjutnya dilakukan penelitian Pengklasteran Mahasiswa Pelamar Beasiswa Dengan Cubic Clustering Criterion. Hasil yang di dapat dari penelitian Penelitian sebelumnya yang telah dilakukan pada tahun ini adalah Dari hasil perhitungan terdapat tiga buah 2020 dengan menggunakan metode K-Medoid pengelompokan untuk untuk data pengajuan beasiswa, diantaranya adalah untuk klasterisasi ibu hamil yaitu kelompok yang tidak diterima, kelompok di beresiko tinggi. dimana hasil klasterisasi sangat pertimbangkan menerima beasiswa dan kelompok membantu dalam penentuan keputusan dalam penerima beasiswa [10]. Kemudian dilakukan kecenderungan-kecenderungan yang terjadi pada ibu penelitian untuk mengelompokan kabupaten/kota pada hamil, serta dapat digunakan dalam menentukan fitur provinsi Sulawesi Selatan dan Barat. Hasil yang yang berpengaruh dalam penanganan kesehatan ibu didapat dari penelitian ini Nilai siluet yang dihasilkan hamil [4].

Selanjutnya dilakukan penelitian dengan judul Algoritma K-Medoids Untuk Menentukan Calon Mahasiswa Yang Layak Mendapatkan Beasiswa Bidikmisi. Hasil pengujian dilakukan dengan aplikasi rapid miner. Kemudian hasil yang di dapat memiliki kesamaan dengan perhitungan manual, dimana Selanjutnya dilakukan penelitian terhadap penerima beasiswa bidikmisi dapat dibentuk kedalam 4 perbandingan algoritma K-Means dan K-Medoid untuk (empat) cluster, cluster 0 terdiri atas 2 anggota, cluster pengelompokan transaksi bongkar muat di provinsi 1 terdiri atas 5 anggota, cluster 2 terdiri atas 2 anggota, Riau. Dari hasil penelitian tersebut didapat Hasil yang dan cluster 3 terdiri atas 2 anggota [5]. Berikutnya pada pengolahan data menunjukkan pengolahan dilakukan penelitian Untuk Pengelompokan Penduduk menggunakan metode K-Means nilai BDI yang Kurang Mampu. Adapun faktor-faktor yang diperoleh lebih rendah dimana nilai k=3 dibandingkan mempengaruhi dalam menentukan calon yang akan dengan K-Medoids nilai $\mathrm{k}=10$. Serta waktu perhitungan menerima bantuan dari pemerintah yaitu pekerjaan, menggunakan K-Means rata-rata 1 detik berbanding status rumah, banyaknya tanggungan dan penghasilan dengan K-Medoids membutuhkan waktu rata-rata $\mathrm{i}$ yang didapat setiap bulannya. Dari hasil perhitungan menit 38 detik [12]. Kemudian dilakukan penelitian iterasi pertama dan iterasi kedua, maka didapatlah hasil terhadap perbandingan algoritma K-Means dan Kpengelompokan penduduk kurang mampu berdasarkan Medoid untuk klasterisasi produk asuransi. Hasil dari pekerjaan, rumah, jumlah tanggungan dan penghasilan. analisi dan pengolahan data maka dapat di simpulkan Penerapan Algoritma K-Medoids dapat mengetahui bahwasanya nilai DBI menggunakan metode K-Means berapa banyak warga kurang mampu yang layak lebih optimal dimana nilai DBI terkecil nya adalah menerima bantuan [6]. Berikutnya dilakukan penelitian pada nilai $\mathrm{k}=5$ yaitu 0,018 [13].

Penerapan Algoritma K-Medoids Clustering dalam Pengelompokkan Penyebaran Diare. Hasil yang di dapat dari penelitian ini adalah dengan dilakukannya perhitungan pengelompokkan penyebaran diare secara cluster menggunakan algoritma k-medoids kita lebih mudah melihat daerah mana saja yang paling banyak terkena penyakit diare. Cluster pertama atau C0 merupakan daerah yang tidak terlalu di fokuskan

\section{Metodologi Penelitian}

\subsection{Kerangka Kerja Penelitian}

Kerangka kerja ini merupakan tahapan-tahapan yang dilakukan dalam memberikan pemecahan permasalahan yang akan dibahas [14]. Adapun dalam penelitian ini kerangka kerjanya yaitu : 
a. Mengenali Ruang Lingkup Masalah.

Pada tahapan ini, merupakan langkah paling awal dan terpentiong dalam melakukan penelitian. Hal ini bertujuan untuk memahami permasalahan dengan jelas serta dapat mengatasi masalah tersebut dengan baik.

b. Menganalisa Permasalahan.

Menganalisa permasalahan yang didapat diharapkan penulis mampu mengenal konteks yang ada didalam permasalahan penelitian tersebut, sehingga penulis dapat mengurutkan langkah-langkah yang akan dilakukan dalam penelitian.

c. Mendalami Studi Literatur.

Pada tahapan ini, penulis mengadakan eksplorasi terhadap landasan-landasan teori yang didapatkan dari beraneka ragam sumber seperti jurnal, buku, dan juga referensi lainnya untuk melengkapi penelitian ini baik dari segi konsep dan teori yang kemudian memiliki acuan yang baik dan relevan.

d. Mengumpulkan Data-Data Mahasiswa yang Akan Diolah.

Pada periode pengumpulan data dengan mengadakan observasi langsung ke sumber data, dengan cara melakukan pengamatan langsung.

e. Mengolah Data Menggunakan Algoritma KMedoid

Seluruh data yang sudah didapatkan tadi kemudian diolah dengan menggunakan data mining. Perhitungan data dilakukan secara manual dengan menggunakan algoritma K-Medoid dengan menghasilkan pengelompokan data mahasiswa yang menyelesaikan masa studi tepat waktu dan mahasiswa yang menyelesaikan masa studi tidak tepat waktu.

f. Melakukan Pengujian Data

Dengan menggunakan data yang sama saat melakukan pengolahan data manual menggunakan algoritma K-Medoid, kemudian data di uji menggunakan aplikasi rapid miner dengan tujuan untuk memadankan antara perhitungan manual dengan perhitungan menggunakan atau berbasis komputer.

g. Menarik Kesimpulan.

Dasi hasil pengolahan data maka didapatkan pengetahuan yang merupakan output dari penelitian ini. Penelitian menghasilkan 2 cluster yaitu mahasiswa yang dapat menyelesaikan masa studi tepat waktu dan mahasiswa yang menyelesaikan masa studi tidak tepat waktu.

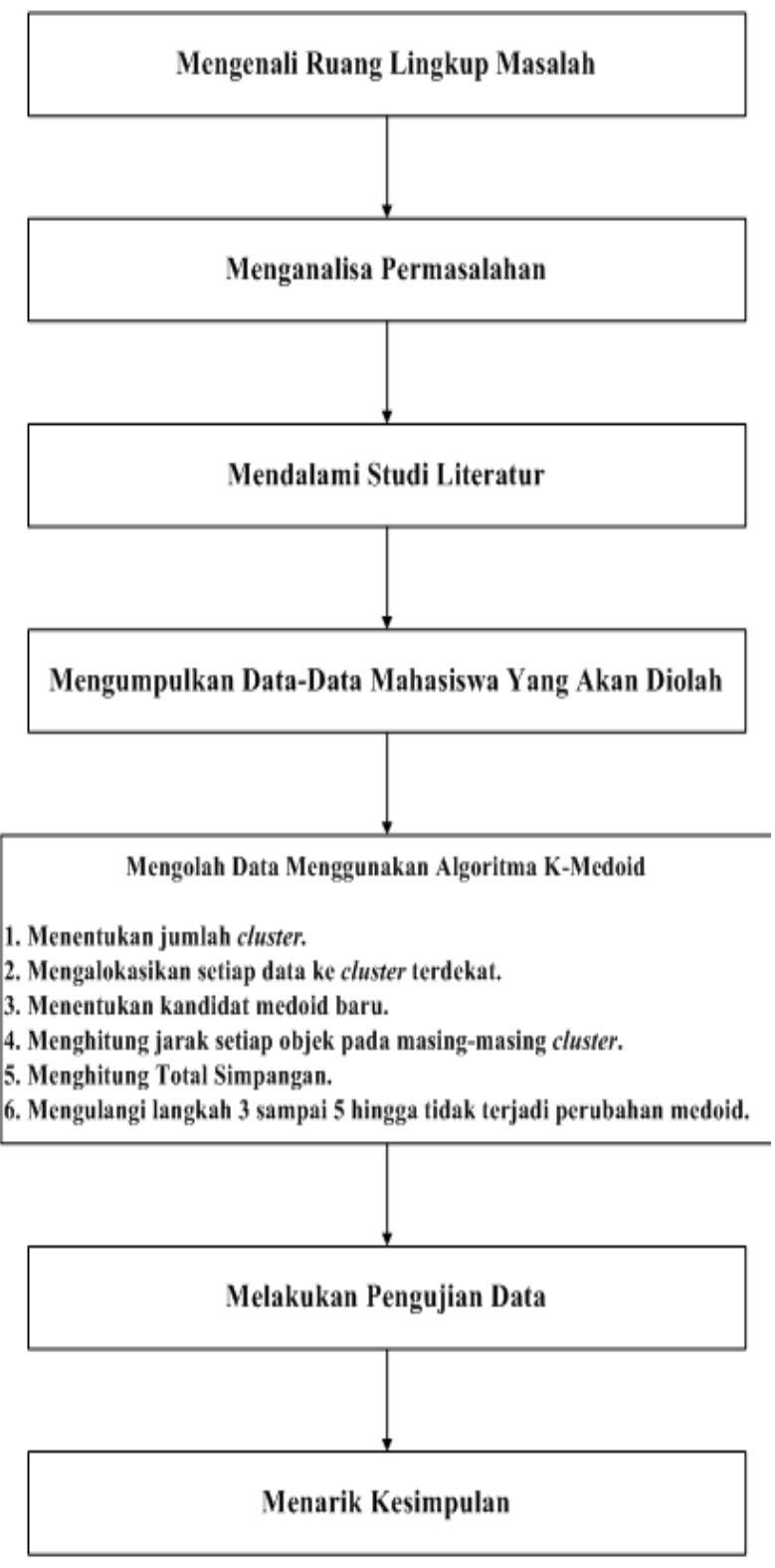

Gambar 1. Kerangka Kerja Penelitian

\subsection{K-Medoid}

Metode k-medoid dikembangkan oleh Leonard Kaufman dan Peter J. Rousseeuw pada tahun 1987. Algoritma K-Medoid sering disebut juga Algoritma Partitoning Around Medoid (PAM). Metode K-Medoid memiliki kesamaan dengan Metode K-Means yaitu sama-sama termasuk Metode Partitioning. Metode Partitioning merupakan metode pengelompokan data kedalam sejumlah cluster tanpa adanya struktur hirarki antara satu dengan yang lainnya [15].

Algoritma K-Medoids menggunakan metode partisi clustering untuk mengelompokkan sejumlah $\mathrm{n}$ objek menjadi sebuah cluster. Algoritma ini menggunakan objek pada sekumpulan objek untuk mewakili sebuah cluster. Objek yang terpilih nantinya disebut dengan medoid. Cluster di buat dengan cara menghitung kedekatan yang dimiliki antara medoid dengan objek non medoid. Langkah-langkah dalam perhitungan algoritma k-medoid antara lain: 
a. Inialisasi pusat cluster sebanyak k (jumlah cluster).

b. Alokasikan setiap data (obek) ke kluster terdekat menggunakan persamaan ukuran jarak Euclidian Distance dengan persamaan :

$Q_{f d} \sqrt{\left(R 1_{f}-R 1_{d}\right)^{2}+\left(R 2_{f}-R 2_{d}\right)^{2}+\ldots+\left(R k_{f}-R K_{d}\right)^{2}}$

c. Pilih secara acak objek pada masing-masing cluster sebagai kandidat medoid baru.

d. Hitung jarak setiap objek yang berada pada masingmasing cluster dengan kandidat medoid baru.

e. Hitung total simpangan (S) dengan menghitung nilai total distance baru - total distance lama. Jika S $<0$, maka tukar objek dengan data cluster untuk membentuk sekumpulan $\mathrm{k}$ objek baru sebagai medoid.

f. Ulangi langkah 3 sampai 5 hingga tidak terjadi perubahan medoid, sehingga didapatkan cluster beserta anggota cluster masing-masing.

\subsection{Analisa Data}

Proses pengumpulan data-data mahasiswa dilakukan dengan cara mendatangi langsung AMIK Tunas Bangsa Pematangsiantar. Data tersebut terdiri dari 136 data mahasiswa. Data-data yang dipakai dala penelitian ini adalah data real. Pada saat penelitian di kampus AMIK Tunas Bangsa Pematangsiantar secara langsung menemui bagian biro pendidikan. Selanjutnya data diolah menggunakan algoritma K-Medoid yang disajikan pada Gambar 2.

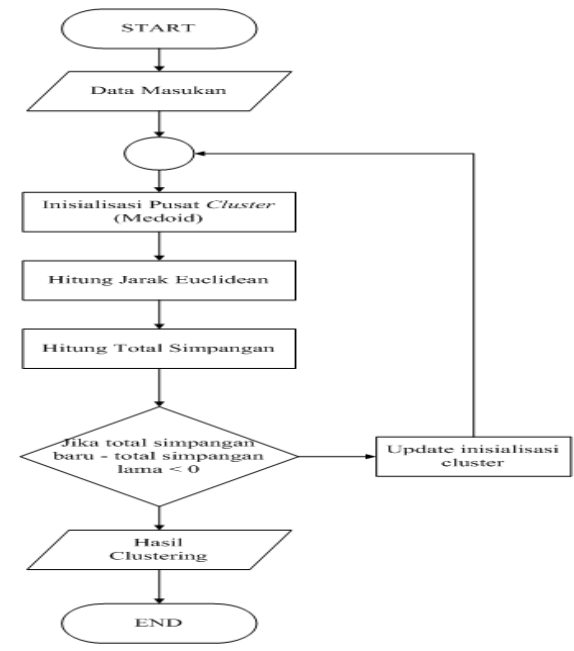

Gambar 2. Flowchart Algoritma K-Medoid
Tabel 1. Data Mahasiswa

\begin{tabular}{|c|c|c|c|c|}
\hline No & Nama & JK & SKS & IPK \\
\hline 1 & MHS 1 & Laki-Laki & 43 & 3.51 \\
\hline 2 & MHS 2 & Laki-Laki & 42 & 2.98 \\
\hline 3 & MHS 3 & Perempuan & 43 & 3.56 \\
\hline 4 & MHS 4 & Laki-Laki & 43 & 3.60 \\
\hline 5 & MHS 5 & Laki-Laki & 39 & 2.76 \\
\hline 6 & MHS 6 & Laki-Laki & 43 & 3.67 \\
\hline 7 & MHS 7 & Laki-Laki & 35 & 2.83 \\
\hline 8 & MHS 8 & Perempuan & 43 & 3.58 \\
\hline 9 & MHS 9 & Laki-Laki & 25 & 1.86 \\
\hline 10 & MHS 10 & Perempuan & 22 & 1.67 \\
\hline 11 & MHS 11 & Perempuan & 43 & 3.53 \\
\hline 12 & MHS 12 & Laki-Laki & 42 & 3.24 \\
\hline 13 & MHS 13 & Laki-Laki & 41 & 2.81 \\
\hline 14 & MHS 14 & Laki-Laki & 38 & 2.93 \\
\hline 15 & MHS 15 & Perempuan & 43 & 3.40 \\
\hline 16 & MHS 16 & Laki-Laki & 43 & 3.35 \\
\hline 17 & MHS 17 & Laki-Laki & 43 & 3.28 \\
\hline 18 & MHS 18 & Laki-Laki & 21 & 1.51 \\
\hline 19 & MHS 19 & Perempuan & 43 & 3.49 \\
\hline 20 & MHS 20 & Laki-Laki & 43 & 3.72 \\
\hline 21 & MHS 21 & Perempuan & 43 & 3.53 \\
\hline 22 & MHS 22 & Perempuan & 43 & 3.51 \\
\hline 23 & MHS 23 & Perempuan & 43 & 3.49 \\
\hline 24 & MHS 24 & Perempuan & 43 & 3.74 \\
\hline 25 & MHS 25 & Laki-Laki & 20 & 1.67 \\
\hline 26 & MHS 26 & Perempuan & 43 & 3.86 \\
\hline 27 & MHS 27 & Perempuan & 39 & 2.88 \\
\hline 28 & MHS 28 & Laki-Laki & 43 & 3.63 \\
\hline 29 & MHS 29 & Laki-Laki & 43 & 3.33 \\
\hline 30 & MHS 30 & Perempuan & 43 & 3.33 \\
\hline 31 & MHS 31 & Laki-Laki & 42 & 3.10 \\
\hline 32 & MHS 32 & Perempuan & 43 & 3.56 \\
\hline 33 & MHS 33 & Perempuan & 43 & 3.56 \\
\hline 34 & MHS 34 & Laki-Laki & 36 & 2.71 \\
\hline 35 & MHS 35 & Perempuan & 43 & 3.51 \\
\hline 36 & MHS 36 & Perempuan & 30 & 2.52 \\
\hline 37 & MHS 37 & Laki-Laki & 43 & 3.51 \\
\hline 38 & MHS 38 & Laki-Laki & 38 & 2.90 \\
\hline 39 & MHS 39 & Laki-Laki & 40 & 2.93 \\
\hline 40 & MHS 40 & Perempuan & 43 & 3.56 \\
\hline 41 & MHS 41 & Laki-Laki & 38 & 2.79 \\
\hline 42 & MHS 42 & Perempuan & 29 & 2.10 \\
\hline 43 & MHS 43 & Laki-Laki & 43 & 3.51 \\
\hline 44 & MHS 44 & Laki-Laki & 39 & 2.95 \\
\hline 45 & MHS 45 & Laki-Laki & 37 & 2.95 \\
\hline 46 & MHS 46 & Perempuan & 43 & 3.40 \\
\hline 47 & MHS 47 & Laki-Laki & 35 & 2.42 \\
\hline 48 & MHS 48 & Perempuan & 43 & 3.44 \\
\hline 49 & MHS 49 & Laki-Laki & 43 & 3.16 \\
\hline 50 & MHS 50 & Perempuan & 43 & 3.21 \\
\hline
\end{tabular}

\section{Hasil dan Pembahasan}

\subsection{Alur Algoritma K-Medoid}

Proses cluster akan dilakukan dengan menggunakan algoritma K-Medoid. Proses akan dimulai dengan memasukkan data yang dibutuhkan, menentukan jumlah cluster. Kemudian dilakukan proses dari seluruh langkah-langkah perhitungan dengan algoritma KMedoid.

Urutan langkah Algoritma K-Medoid adalah:

a. Menentukan jumlah cluster, dimana sampel data mahasiswa yang digunakan dalam proses cluster sebanyak 136 mahasiswa. 
Fahmi Firzada, Yuhandri Yunus.

b. Inisialisasi pusat cluster sebanyak 2 cluster dari data mahasiswa. Untuk penetapan setiap medoid dipilih secara acak. Seperti pada Tabel 2.

Tabel 2. Medoid Awal

\begin{tabular}{cccc}
\hline NAMA & JK & SKS & IPK \\
\hline MHS 47 & 1 & 35 & 2,42 \\
MHS 50 & 2 & 43 & 3,21 \\
\hline
\end{tabular}

c. Menghitung nilai cost dengan persamaan Euclidian Distance: untuk menghitung jarak antara titik centroid dengan titik tiap objek menggunakan Euclidian Distance. Berikut adalah perhitungan jarak pada data mahasiswa.

$$
\begin{aligned}
& Q_{1,1} \sqrt{(1-1)^{2}+(35-43)^{2}+(2,42-3,51)^{2}} \\
& \quad=8,0739 \\
& \begin{aligned}
Q_{1,2} & \sqrt{(2-1)^{2}+(43-43)^{2}+(3,21-3,51)^{2}} \\
& =1,0440
\end{aligned} \\
& \begin{aligned}
Q_{2,1} & \sqrt{(1-1)^{2}+(35-42)^{2}+(2,42-2,98)^{2}} \\
& =7,0224 \\
Q_{2,2} & \sqrt{(2-1)^{2}+(43-42)^{2}+(3,21-2,98)^{2}} \\
& =1,4328 \\
Q_{3,1} & \sqrt{(1-1)^{2}+(35-43)^{2}+(2,42-3,56)^{2}} \\
& =8,1425
\end{aligned} \\
& \begin{aligned}
Q_{3,2} & \sqrt{(2-1)^{2}+(43-43)^{2}+(3,21-3,56)^{2}} \\
& =0,35
\end{aligned}
\end{aligned}
$$

\begin{tabular}{|c|c|c|c|c|c|}
\hline No & Nama & Cost 1 & Cost 2 & Kedekatan & Cluster \\
\hline 1 & MHS 1 & 8,074 & 1,044 & 1,044 & 1 \\
\hline 2 & MHS 2 & 7,022 & 1,433 & 1,433 & 1 \\
\hline 3 & MHS 3 & 8,142 & 0,350 & 0,350 & 1 \\
\hline 4 & MHS 4 & 8,087 & 1,073 & 1,073 & 1 \\
\hline 5 & MHS 5 & 4,014 & 4,148 & 4,014 & 2 \\
\hline 6 & MHS 6 & 8,097 & 1,101 & 1,101 & 1 \\
\hline 7 & MHS 7 & 0,410 & 8,071 & 0,410 & 2 \\
\hline 8 & MHS 8 & 8,145 & 0,370 & 0,370 & 1 \\
\hline 9 & MHS 9 & 10,016 & 18,078 & 10,016 & 2 \\
\hline 10 & MHS 10 & 13,060 & 21,056 & 13,060 & 2 \\
\hline 11 & MHS 11 & 8,138 & 0,320 & 0,320 & 1 \\
\hline 12 & MHS 12 & 7,048 & 1,415 & 1,415 & 1 \\
\hline 13 & MHS 13 & 6,013 & 2,272 & 2,272 & 1 \\
\hline 14 & MHS 14 & 3,043 & 5,107 & 3,043 & 2 \\
\hline 15 & MHS 15 & 8,122 & 0,190 & 0,190 & 1 \\
\hline 16 & MHS 16 & 8,054 & 1,010 & 1,010 & 1 \\
\hline 17 & MHS 17 & 8,046 & 1,002 & 1,002 & 1 \\
\hline 18 & MHS 18 & 14,030 & 22,088 & 14,030 & 2 \\
\hline 19 & MHS 19 & 8,133 & 0,280 & 0,280 & 1 \\
\hline 20 & MHS 20 & 8,105 & 1,123 & 1,123 & 1 \\
\hline 21 & MHS 21 & 8,138 & 0,320 & 0,320 & 1 \\
\hline 22 & MHS 22 & 8,136 & 0,300 & 0,300 & 1 \\
\hline 23 & MHS 23 & 8,133 & 0,280 & 0,280 & 1 \\
\hline 24 & MHS 24 & 8,170 & 0,530 & 0,530 & 1 \\
\hline 25 & MHS 25 & 15,019 & 23,073 & 15,019 & 2 \\
\hline 26 & MHS 26 & 8,190 & 0,650 & 0,650 & 1 \\
\hline 27 & MHS 27 & 4,149 & 4,014 & 4,014 & 1 \\
\hline 28 & MHS 28 & 8,091 & 1,085 & 1,085 & 1 \\
\hline 29 & MHS 29 & 8,052 & 1,007 & 1,007 & 1 \\
\hline 30 & MHS 30 & 8,113 & 0,120 & 0,120 & 1 \\
\hline 31 & MHS 31 & 7,033 & 1,418 & 1,418 & 1 \\
\hline 32 & MHS 32 & 8,142 & 0,350 & 0,350 & 1 \\
\hline 33 & MHS 33 & 8,142 & 0,350 & 0,350 & 1 \\
\hline 34 & MHS 34 & 1,041 & 7,089 & 1,041 & 2 \\
\hline 35 & MHS 35 & 8,136 & 0,300 & 0,300 & 1 \\
\hline 36 & MHS 36 & 5,100 & 13,018 & 5,100 & 2 \\
\hline 37 & MHS 37 & 8,074 & 1,044 & 1,044 & 1 \\
\hline 38 & MHS 38 & 3,038 & 5,108 & 3,038 & 2 \\
\hline 39 & MHS 39 & 5,026 & 3,175 & 3,175 & 1 \\
\hline 40 & MHS 40 & 8,142 & 0,350 & 0,350 & 1 \\
\hline 41 & MHS 41 & 3,023 & 5,116 & 3,023 & 2 \\
\hline 42 & MHS 42 & 6,091 & 14,044 & 6,091 & 2 \\
\hline 43 & MHS 43 & 8,074 & 1,044 & 1,044 & 1 \\
\hline 44 & MHS 44 & 4,035 & 4,131 & 4,035 & 2 \\
\hline 45 & MHS 45 & 2,069 & 6,088 & 2,069 & 2 \\
\hline 46 & MHS 46 & 8,122 & 0,190 & 0,190 & 1 \\
\hline 47 & MHS 47 & 0,000 & 8,101 & 0,000 & 2 \\
\hline 48 & MHS 48 & 8,127 & 0,230 & 0,230 & 1 \\
\hline 49 & MHS 49 & 8,034 & 1,001 & 1,001 & 1 \\
\hline 50 & MHS 50 & 8,101 & 0,000 & 0,000 & 1 \\
\hline
\end{tabular}

d. Setelah didapatkan nilai cost pada iterasi pertama maka proses berikutnya lanjut ke iterasi kedua. Kandidat medoid baru (non medoid) pada iterasi kedua dapat dilihat pada Tabel 4.

Tabel 4. Non Medoid

\begin{tabular}{cccc}
\hline NAMA & JK & SKS & IPK \\
\hline MHS 26 & 2 & 43 & 3,86 \\
MHS 27 & 2 & 39 & 2,88 \\
\hline
\end{tabular}

Tabel 3. Hasil Perhitungan Medoid Awal

Memasukkan kembali objek-objek non medoid kedalam cluster yang paling dekat dengan medoid berdasarkan jarak euclidean. Berikut ini adalah perhitungan jarak pada data mahasiswa :

$$
\begin{aligned}
& Q_{1,1} \sqrt{(2-1)^{2}+(43-43)^{2}+(3,86-3,51)^{2}} \\
& \quad=1,059 \\
& \begin{aligned}
Q_{1,2} & \sqrt{(2-1)^{2}+(29-43)^{2}+(2,88-3,51)^{2}} \\
& =4,171
\end{aligned} \\
& \begin{aligned}
Q_{2,1} & \sqrt{(2-1)^{2}+(43-42)^{2}+(3,86-2,98)^{2}} \\
& =1,666 \\
Q_{2,2} & \sqrt{(2-1)^{2}+(39-42)^{2}+(2,88-2,98)^{2}} \\
& =3,164
\end{aligned}
\end{aligned}
$$




$$
\begin{aligned}
& Q_{3,1} \sqrt{(2-2)^{2}+(43-43)^{2}+(3,86-3,56)^{2}} \\
& \quad=0,300 \\
& Q_{3,2} \sqrt{(2-2)^{2}+(39-43)^{2}+(2,88-3,56)^{2}} \\
& \quad=4,057
\end{aligned}
$$

\begin{tabular}{|c|c|c|c|c|c|}
\hline NO & NAMA & Cost 1 & Cost 2 & Kedekatan & Cluster \\
\hline 1 & MHS 1 & 1,059 & 4,171 & 1,059 & 2 \\
\hline 2 & MHS 2 & 1,666 & 3,164 & 1,666 & 2 \\
\hline 3 & MHS 3 & 0,300 & 4,057 & 0,300 & 2 \\
\hline 4 & MHS 4 & 1,033 & 4,185 & 1,033 & 2 \\
\hline 5 & MHS 5 & 4,267 & 1,007 & 1,007 & 1 \\
\hline 6 & MHS 6 & 1,018 & 4,198 & 1,018 & 2 \\
\hline 7 & MHS 7 & 8,128 & 4,123 & 4,123 & 1 \\
\hline 8 & MHS 8 & 0,280 & 4,061 & 0,280 & 2 \\
\hline 9 & MHS 9 & 18,138 & 14,073 & 14,073 & 1 \\
\hline 10 & MHS 10 & 21,114 & 17,043 & 17,043 & 1 \\
\hline 11 & MHS 11 & 0,330 & 4,052 & 0,330 & 2 \\
\hline 12 & MHS 12 & 1,544 & 3,183 & 1,544 & 2 \\
\hline 13 & MHS 13 & 2,470 & 2,237 & 2,237 & 1 \\
\hline 14 & MHS 14 & 5,183 & 1,415 & 1,415 & 1 \\
\hline 15 & MHS 15 & 0,460 & 4,034 & 0,460 & 2 \\
\hline 16 & MHS 16 & 1,123 & 4,150 & 1,123 & 2 \\
\hline 17 & MHS 17 & 1,156 & 4,142 & 1,156 & 2 \\
\hline 18 & MHS 18 & 22,148 & 18,080 & 18,080 & 1 \\
\hline 19 & MHS 19 & 0,370 & 4,046 & 0,370 & 2 \\
\hline 20 & MHS 20 & 1,010 & 4,208 & 1,010 & 2 \\
\hline 21 & MHS 21 & 0,330 & 4,052 & 0,330 & 2 \\
\hline 22 & MHS 22 & 0,350 & 4,049 & 0,350 & 2 \\
\hline 23 & MHS 23 & 0,370 & 4,046 & 0,370 & 2 \\
\hline 24 & MHS 24 & 0,120 & 4,091 & 0,120 & 2 \\
\hline 25 & MHS 25 & 23,126 & 19,065 & 19,065 & 1 \\
\hline 26 & MHS 26 & 0,000 & 4,118 & 0,000 & 2 \\
\hline 27 & MHS 27 & 4,118 & 0,000 & 0,000 & 1 \\
\hline 28 & MHS 28 & 1,026 & 4,191 & 1,026 & 2 \\
\hline 29 & MHS 29 & 1,132 & 4,148 & 1,132 & 2 \\
\hline 30 & MHS 30 & 0,530 & 4,025 & 0,530 & 2 \\
\hline 31 & MHS 31 & 1,605 & 3,170 & 1,605 & 2 \\
\hline 32 & MHS 32 & 0,300 & 4,057 & 0,300 & 2 \\
\hline 33 & MHS 33 & 0,300 & 4,057 & 0,300 & 2 \\
\hline 34 & MHS 34 & 7,164 & 3,167 & 3,167 & 1 \\
\hline 35 & MHS 35 & 0,350 & 4,049 & 0,350 & 2 \\
\hline 36 & MHS 36 & 13,069 & 9,007 & 9,007 & 1 \\
\hline 37 & MHS 37 & 1,059 & 4,171 & 1,059 & 2 \\
\hline 38 & MHS 38 & 5,189 & 1,414 & 1,414 & 1 \\
\hline 39 & MHS 39 & 3,296 & 1,415 & 1,415 & 1 \\
\hline 40 & MHS 40 & 0,300 & 4,057 & 0,300 & 2 \\
\hline 41 & MHS 41 & 5,210 & 1,417 & 1,417 & 1 \\
\hline 42 & MHS 42 & 14,110 & 10,030 & 10,030 & 1 \\
\hline 43 & MHS 43 & 1,059 & 4,171 & 1,059 & 2 \\
\hline 44 & MHS 44 & 4,222 & 1,002 & 1,002 & 1 \\
\hline 45 & MHS 45 & 6,150 & 2,237 & 2,237 & 1 \\
\hline 46 & MHS 46 & 0,460 & 4,034 & 0,460 & 2 \\
\hline 47 & MHS 47 & 8,190 & 4,149 & 4,149 & 1 \\
\hline 48 & MHS 48 & 0,420 & 4,039 & 0,420 & 2 \\
\hline 49 & MHS 49 & 1,221 & 4,133 & 1,221 & 2 \\
\hline 50 & MHS 50 & 0,650 & 4,014 & 0,650 & 2 \\
\hline
\end{tabular}

Hasil perhitungan jarak ke setiap non medoid baru dapat dilihat pada Tabel 5 .

Tabel 5. Tabel Perhitungan Non Medoid

e. Setelah didapatkan nilai jarak pada iterasi kedua, selanjutnya menghitung total simpangan (S) dengan mencari nilai selisih dari total distance baru - total distance lama. Dengan ketentuan jika $\mathrm{S}<0$ maka tukar objek dengan data cluster untuk membentuk sekumpulan k objek baru sebagai medoid.

$\mathrm{S}=$ Total Distance Baru - Total Distance Lama $=133,814-114,728$

$$
=19,086
$$

\begin{tabular}{|c|c|c|c|c|c|}
\hline No & Nama & Cost 1 & Cost 2 & Kedekatan & Cluster \\
\hline 1 & MHS 1 & 8,074 & 1,044 & 1,044 & 1 \\
\hline 2 & MHS 2 & 7,022 & 1,433 & 1,433 & 1 \\
\hline 3 & MHS 3 & 8,142 & 0,350 & 0,350 & 1 \\
\hline 4 & MHS 4 & 8,087 & 1,073 & 1,073 & 1 \\
\hline 5 & MHS 6 & 8,097 & 1,101 & 1,101 & 1 \\
\hline 6 & MHS 8 & 8,145 & 0,370 & 0,370 & 1 \\
\hline 7 & MHS 11 & 8,138 & 0,320 & 0,320 & 1 \\
\hline 8 & MHS 12 & 7,048 & 1,415 & 1,415 & 1 \\
\hline 9 & MHS 13 & 6,013 & 2,272 & 2,272 & 1 \\
\hline 10 & MHS 15 & 8,122 & 0,190 & 0,190 & 1 \\
\hline 11 & MHS 16 & 8,054 & 1,010 & 1,010 & 1 \\
\hline 12 & MHS 17 & 8,046 & 1,002 & 1,002 & 1 \\
\hline 13 & MHS 19 & 8,133 & 0,280 & 0,280 & 1 \\
\hline 14 & MHS 20 & 8,105 & 1,123 & 1,123 & 1 \\
\hline 15 & MHS 21 & 8,138 & 0,320 & 0,320 & 1 \\
\hline 16 & MHS 22 & 8,136 & 0,300 & 0,300 & 1 \\
\hline 17 & MHS 23 & 8,133 & 0,280 & 0,280 & 1 \\
\hline 18 & MHS 24 & 8,170 & 0,530 & 0,530 & 1 \\
\hline 19 & MHS 26 & 8,190 & 0,650 & 0,650 & 1 \\
\hline 20 & MHS 27 & 4,149 & 4,014 & 4,014 & 1 \\
\hline 21 & MHS 28 & 8,091 & 1,085 & 1,085 & 1 \\
\hline 22 & MHS 29 & 8,052 & 1,007 & 1,007 & 1 \\
\hline 23 & MHS 30 & 8,113 & 0,120 & 0,120 & 1 \\
\hline 24 & MHS 31 & 7,033 & 1,418 & 1,418 & 1 \\
\hline 25 & MHS 32 & 8,142 & 0,350 & 0,350 & 1 \\
\hline 26 & MHS 33 & 8,142 & 0,350 & 0,350 & 1 \\
\hline 27 & MHS 35 & 8,136 & 0,300 & 0,300 & 1 \\
\hline 28 & MHS 37 & 8,074 & 1,044 & 1,044 & 1 \\
\hline 29 & MHS 39 & 5,026 & 3,175 & 3,175 & 1 \\
\hline 30 & MHS 40 & 8,142 & 0,350 & 0,350 & 1 \\
\hline 31 & MHS 43 & 8,074 & 1,044 & 1,044 & 1 \\
\hline 32 & MHS 46 & 8,122 & 0,190 & 0,190 & 1 \\
\hline 33 & MHS 48 & 8,127 & 0,230 & 0,230 & 1 \\
\hline 34 & MHS 49 & 8,034 & 1,001 & 1,001 & 1 \\
\hline 35 & MHS 50 & 8,101 & 0,000 & 0,000 & 1 \\
\hline 36 & MHS 5 & 4,014 & 4,148 & 4,014 & 2 \\
\hline 37 & MHS 7 & 0,410 & 8,071 & 0,410 & 2 \\
\hline 38 & MHS 9 & 10,016 & 18,078 & 10,016 & 2 \\
\hline 39 & MHS 10 & 13,060 & 21,056 & 13,060 & 2 \\
\hline 40 & MHS 14 & 3,043 & 5,107 & 3,043 & 2 \\
\hline 41 & MHS 18 & 14,030 & 22,088 & 14,030 & 2 \\
\hline 42 & MHS 25 & 15,019 & 23,073 & 15,019 & 2 \\
\hline 43 & MHS 34 & 1,041 & 7,089 & 1,041 & 2 \\
\hline 44 & MHS 36 & 5,100 & 13,018 & 5,100 & 2 \\
\hline 45 & MHS 38 & 3,038 & 5,108 & 3,038 & 2 \\
\hline 46 & MHS 41 & 3,023 & 5,116 & 3,023 & 2 \\
\hline 47 & MHS 42 & 6,091 & 14,044 & 6,091 & 2 \\
\hline 48 & MHS 44 & 4,035 & 4,131 & 4,035 & 2 \\
\hline 49 & MHS 45 & 2,069 & 6,088 & 2,069 & 2 \\
\hline 50 & MHS 47 & 0,000 & 8,101 & 0,000 & 2 \\
\hline
\end{tabular}

Dengan nilai $\mathrm{S}>0$ maka proses cluster dihentikan, sehingga diperoleh anggota tiap cluster yang dapat dilihat pada Tabel 6 .

Tabel 6. Hasil Proses Klasterisasi K-Medoid

\section{Kesimpulan}

Metode clustering Algoritma K-Medoid dapat diterapkan di kampus AMIK Tunas Bangsa untuk menghasilkan suatu informasi yang bermanfaat bagi pihak pendidikan dalam melakukan kegiatan-kegiatan untukmeminimalisir jumlah mahasiswa yang diprediksi tidak dapat menyelesaikan masa studi tepat waktu.Dari hasil proses clusterisasi dengan algoritma K-Medoid yang dilakukan maka didapat hasil dari 50 orang maahasiswa, 35 mahasiswa masuk kedalam cluster mahasiswa yang dapat meneyelesaikan masa studi tepat waktu, sedangkan sebanyak 15 orang mahasiswa masuk 
kedalam cluster mahasiswa yang tidak dapat menyelesaikan masa studi tepat waktu.

\section{Daftar Rujukan}

[1] Hardiyanti, F., Tambunan, H. S., \& Saragih, I. S. (2019). Penerapan Metode K-Medoids Clustering pada Penanganan Kasus Diare di Indonesia. KOMIK (Konferensi Nasional Teknologi Informasi dan Komputer), 3(1), 2598-4645. DOI: http://dx.doi.org/10.30865/komik.v3i1.1666 .

[2] Rofiqi, A. Y. (2017). Clustering Berita Olahraga Berbahasa Indonesia Menggunakan Metode K-Medoid Bersyarat. Jurnal Simantec, 6(1)

[3] Gita, T. P. (2015). Penerapan Metode Klastering dengan Algoritma K-Means Untuk Prediksi Kelulusan Mahasiswa Pada Program Studi Teknik Informatika Strata Satu. Udinus Repository.

[4] Riadi, M., Azhar, Y., \& Wicaksono, G. W. (2020). Implementasi Algoritma C5.0 dan K-Medoids Untuk Klasterisasi Ibu Hamil Beresiko Tinggi. Jurnal Repositor, 2(4), 511-524. DOI: http://doi:10.22219/repositor.v2i4.696

[5] Buulolo, E., Syahputra, R., \& Fau, A. (2020). Algoritma KMedoids Untuk Menentukan Calon Mahasiswa yang Layak Mendapatkan Beasiswa Bidikmisi di Universitas Budi Darma. Jurnal Media Informatika Budidarma, 4(3). DOI: http://dx.doi.org/10.30865/mib.v4i3.2240 .

[6] Arianto, J. (2019). Penerapan Data Mining Untuk Pengelompokan Penduduk Kurang Mampu Desa Sambirejo Timur dengan Algoritma K-Medoids (Studi Kasus Kantor Kepala Desa Sambirejo Timur). Komik (Konferensi Nasional Teknologi Informasi dan Komputer), 3(1). DOI: http://dx.doi.org/10.30865/komik.v3i1.1660 .

[7] Riyanto, B. (2019). Penerapan Algoritma K-Medoids Clustering Untuk Pengelompokkan Penyebaran Diare di Kota Medan (Studi Kasus: Kantor Dinas Kesehatan Kota Medan). KOMIK (Konferensi Nasional Teknologi Informasi dan Komputer), 3(1). DOI: http://dx.doi.org/10.30865/komik.v3i1.1659

[8] Wahyuli, D., Handrizal, H., Parlina, I., Windarto, A. P., Suhendro, D., \& Wanto, A. (2019). Mengelompokkan Garis Kemiskinan Menurut Provinsi Menggunakan Algoritma K-
Medoids. Prosiding Seminar Nasional Riset Information Science (SENARIS), 1. DOI: http://dx.doi.org/10.30645/senaris.v1i0.51 .

[9] Ningsih, S., Suhada, S., Dewi, R., \& Windarto, A. P. (2019). Pengklasteran Dokumen Tentang Dispensasi Nikah Menggunakan Algoritma K-Medoids. Prosiding Seminar Nasional Riset Information Science (SENARIS), 1. DOI: http://dx.doi.org/10.30645/senaris.v1i0.74 .

[10]Defiyanti, S., Jajuli, M., \& Rohmawati, N. (2017). Optimalisasi K-MEDOID dalam Pengklasteran Mahasiswa Pelamar Beasiswa dengan Cubic Clustering Criterion. Jurnal Nasional Teknologi dan Sistem Informasi, 3(1), 211-218. DOI: http://doi:10.25077/teknosi.v3i1.2017.211-218 .

[11]Triyanto, W. A. (2015). Algoritma K-Medoids Untuk Penentuan Strategi PemasaranProduk. Jurnal SIMETRIS, 6(1), 2252-4983. DOI: https://doi.org/10.24176/simet.v6i1.254

[12] Anggreini, N. L. (2019). Teknik Clustering dengan Algoritma KMedoids Untuk Menangani Strategi Promosi di Politeknik TEDC Bandung. Jurnal Teknologi Informasi dan Pendidikan, 12(2), 2086-4981. DOI: https://doi.org/10.24036/tip.v12i2.215

[13]AS, W., Aidid, M. K., \& Nusrang, M. (2019). Pengelompokan Kabupaten/Kota Provinsi Sulawesi Selatan dan Barat Berdasarkan Angka Partisipasi Pendidikan SMA/SMK/MA Menggunakan K-Medoid dan CLARA. VARIANSI: Journal of Statistics and Its Application on Teaching and Research, 1(3), 48. DOI: https://doi.org/10.35580/variansiunm12899.

[14]Kamila, I., Khairunnisa, U., \& Mustakim, M. (2019). Perbandingan Algoritma K-Means dan K-Medoids untuk Pengelompokan Data Transaksi Bongkar Muat di Provinsi Riau. Jurnal Ilmiah Rekayasa dan Manajemen Sistem Informasi, 5(1). DOI: http://dx.doi.org/10.24014/rmsi.v5i1.7381

[15] Farahdinna, F., Nurdiansyah, I., Suryani, A., \& Wibowo, A. (2019). Perbandingan Algoritma K-Means dan K-Medoids dalam Klasterisasi Produk Asuransi Perusahaan Nasional. Jurnal Ilmiah Fifo, 11(2). DOI: http://dx.doi.org/10.22441/fifo.2019.v11i2.010 